\title{
OPTIMIZATION OF THE ENZYME ASSISTED EXTRACTION OF ESSENTIAL OIL FROM THE LEAVES AND BRANCHES OF CINNAMOMUM CASSIA USING BOX-WILSON METHOD
}

\author{
Hoang Thi Bich ${ }^{1,2}$, Le Mai Huong ${ }^{1}$, Nguyen Quyet Chien ${ }^{1}$, Dinh Thi Thu Thuy ${ }^{1}$, \\ Le Tat Thanh ${ }^{1}$, Do Trung $\mathrm{Sy}^{3}$, Le Thi Thuy Hang ${ }^{4}$, Pham Hong Hai ${ }^{1}$ \\ ${ }^{1}$ Institute of Natural Products Chemistry, VAST, 18 Hoang Quoc Viet, Ha Noi \\ ${ }^{2}$ Graduate University of Science and Technology, VAST, 18 Hoang Quoc Viet, Ha Noi \\ ${ }^{3}$ Institute of Chemistry, VAST, 18 Hoang Quoc Viet, Ha Noi \\ ${ }^{4}$ Quality Assurance and Testing Center 1, Directorate for Standards, Metrology and Quality, \\ 08 Hoang Quoc Viet, Ha Noi \\ "Email: bichhoang.inpc@gmail.com
}

Received: 6 April 2017; Accepted for publication: 23 October 2017

\begin{abstract}
The process of enzyme assisted extraction of essential oil from the leaves and branches of the Vietnamese aromatic plant Cinnamomum cassia was studied and optimized using a Box-Wilson central composite design consisting of 05 independent variables $(\mathrm{pH}$, temperature $\mathrm{T}$, time $\tau$, concentration of the enzyme Laccase, and concentration of the enzyme Cellic Htec2), and two dependent variables (reducing sugar and yield of essential oil). Secondorder polynomial equations were obtained for the responses, which fitted well with the experimental data. Optimal conditions for oil yield were found at $\mathrm{pH}=5.2 ; \mathrm{T}=44^{\circ} \mathrm{C} ; \tau=5 \mathrm{~h} 30^{\prime}$; Laccase $=0.42 \mathrm{ml} / \mathrm{g}$, and Cellic Htec $2=1.15 \%$. The experimental value $(0.982 \%$ oil yield $)$ was close to the predicted value $(0.978 \%)$. The application of enzyme assisted extraction in combination with optimization using response surface methodology substantially improved the oil yield as compared with traditional method.
\end{abstract}

Keywords: optimization, Box-Wilson central composite design, enzyme assisted extraction, essential oil, Cinnamomum cassia.

\section{INTRODUCTION}

Cinnamomum cassia (L.) J. Presl (Vietnamese: Quế đơn, English: Chinese cassia or Chinese cinnamon, Family Lauraceae) is a tropical evergreen tree well-known for its bark (cassia bark) and essential oil (cassia oil) which are widely used as spice and aromatic material in food, pharmaceutical, and cosmetic industry, as well as in household. Cinnamomum cassia has its origin in Vietnam and is cultivated here since very early time for domestic consumption 
and export (China, USA, UK, Germany, etc.). Annually Vietnam produces thousands of tones of cassia bark and up to one hundred tones of cassia oil [1].

Cassia bark is taken directly from the trees after cutting, while cassia oil is traditionally extracted from the leaves and branches by simple hydrodistillation. There is an urgent need in improving the technique to achieve higher oil yield and shorter distillation time. Approaching this need, we have recently been successful in applying the principle of enzyme assisted extraction (EAE) to this process [2]. Through enzymatic treatment of the raw material with a combination of the enzymes Laccase (from Ganoderma lucidum) and Cellic Htec2 (Novozyme, Denmark) before distillation substantial improvement of the yield of essential oil and distillation time has been achieved. We also observed in this study that several parameters including $\mathrm{pH}$, temperature, fermentation time, concentration and ratio of enzymes showed significant effects on the outcome of the process and needed to be optimized.

Recently there have been an ever increasing number of reports on successful applications of the response surface methodology for the optimization of processes in chemistry and biotechnology similar to ours [3,4]. This encouraged us to employ this useful mathematicstatistical tool for the establishment of a statistical model of our above process and the estimation of optimal conditions. For this purpose, the Box-Wilson central composite design, which is a response surface methodology, was used. Five parameters were chosen as independent variables. Two responses, namely, the outcome of total reducing sugar and the yield of essential oil, were chosen as dependent variables.

\section{MATERIALS AND METHODS}

\subsection{Materials}

Samples of Cinnamomum cassia (L.) J.Presl (Lauraceae) were collected in Van Yen district, Yenbai province. Leaves and branches were dried in the shadow and then finely ground into a powder with a size smaller than $3 \mathrm{~mm}$, packed in polyethylene bags under vacuum, and stored in the dark at room temperature until use.

\subsection{Enzyme}

The crude Laccase was isolated from culture medium of the fungus Ganoderma lucidum (provided by Vietnam Agricultural Genetics Institute). For Laccase production, G. lucidum was cultivated in $150 \mathrm{ml}$ fermentation medium in a $500 \mathrm{ml}$ Erlenmeyer flask at $30^{\circ} \mathrm{C}$ with shaking at $150 \mathrm{rpm}$. Fermentation medium was composed of $50 \%$ potato dextrose, $10 \mathrm{~g}$ glucose, $2 \mathrm{~g} \mathrm{MgSO} 4 \cdot 7 \mathrm{H}_{2} \mathrm{O}$ and $3 \mathrm{~g} \mathrm{KH}_{2} \mathrm{PO}_{4}$ per liter. Culture broth was then filtered, centrifuged to remove cell biomass (at 10,000 rpm for 30 minutes) and reduced the volume by precipitation with alcohol which was removed to achieve a solution of the crude Laccase. Laccase activity was determined spectrophotometrically by measuring the increase in absorbance at $420 \mathrm{~nm}, 30{ }^{\circ} \mathrm{C}$ using $1 \mathrm{mM}$ ABTS (2,2'-di--azino [3-ethyl-benzothiazolinsulphonate]) as substrate.

Cellic Htec 2, an enzyme preparation consisting of cellulase and xylanase, was purchased from Novozymes (Bagsvaerd, Denmark).

Enzyme activity was assayed and presented in Table 1. 
Table 1. Enzyme activities.

\begin{tabular}{|c|l|c|c|c|c|}
\hline $\mathbf{N}^{\mathbf{0}}$ & \multicolumn{1}{|c|}{ Enzymes } & Assays & Substrates & Unit & Activity \\
\hline 1 & Crude enzymes from G. lucidum & Laccase & ABTS & UI/ml & 185 \\
\hline \multirow{2}{*}{2} & \multirow{2}{*}{ Cellic Htec2 } & Cellulase & CMC & UI/ml & 2800 \\
& & Xylanase & Xylan & & 1500 \\
\hline
\end{tabular}

\subsection{Extraction of essential oil}

Essential oil was extracted from plant materials by hydrodistillation. Before extraction, $100 \mathrm{~g}$ of cassia leaves and branches powder were subjected to a preliminary treatment by soaking in water for 24 hours (material/water 1:5, g/ml). Then, the material was steam distilled in a 21 Clevenger-type apparatus for specified times ( $2-8$ hours). The obtained essential oil was dried over anhydrous sodium sulfate and stored in a sealed vial at $10{ }^{\circ} \mathrm{C}$ in the dark prior to analysis. Oil yield is calculated based on the mass of essential oil obtained and the mass of the initial material.

$$
\text { Essential oil content }(\%)=\frac{\text { Weight of essential oil }}{\text { Weight of raw materials }} \times 100 \%
$$

\subsection{Treatment of cassia powder with enzymes}

$100 \mathrm{~g}$ of cassia leaves and branches powder were first pre-treated as described above, then put into a $2 \mathrm{~L}$ glass beaker equipped with a hot plate and a stirrer. After adjusting the medium to a $\mathrm{pH}$ value of 5.0, specified amounts of enzymes were added (crude Laccase and Cellic Htec2 enzyme). Incubation was then performed under stirring (90 - $120 \mathrm{rpm}$ ) at $45^{\circ} \mathrm{C}$ for 12 hours.

For analysis, $20 \mathrm{~mL}$ of the reaction product was taken and centrifuged at $6,000 \mathrm{rpm}$ for 15 minutes. The liquid part was used for the determination of reducing sugars. The contents of reducing sugars in the plant materials before and after the enzymatic treatment were determined by the DNS method as described by Miller (1959), using glucose as reference standard [5].

Mixture of cassia leaves and branches after hydrolysis were then subjected to hydrodistillation for essential oil using a Clevenger apparatus. The essential oil content is determined according to the Viet Nam Pharmacopoeia IV [6].

$$
\text { Essential oil content }(\%)=\frac{\text { Weigh of essential oil }}{\text { Weigh of raw materials }} \times 100 \%
$$

\subsection{Optimization of hydrolysis}

Response surface methodology, in particular the Box-Wilson central composite design [7] was employed to estimate the effect of 5 reaction parameters $(\mathrm{pH}$, temperature, reaction time, Laccase concentration, and Htec2 concentration) on reducing sugar output and yield of essential oil. Procedures for the construction of the $2^{5-1}$ orthogonal design matrix, for the mathematicalstatistical treatments, and for the determination of optimal conditions followed instructions described by Pham Hong Hai (2007) [8]. Regression validation was performed using the Student t-test and the Fisher F-test. 


\section{RESULTS AND DISCUSSION}

\subsection{Selection of variables and construction of the design matrix}

Based on our prior experiments, 05 reaction parameters, including $\mathrm{pH}\left(\mathrm{X}_{1}\right)$, temperature $\left(X_{2}\right)$, reaction time $\left(X_{3}\right)$, concentration of the enzyme Laccase $\left(X_{4}\right)$, and concentration of the enzyme Htec2 $\left(\mathrm{X}_{5}\right)$, were chosen as independent variables for the design of experiments (Table 2) because of their observed effects on the outcome of the process. The outcome (concentration) of total reducing sugar $\left(\mathrm{y}_{1}, \mathrm{~g} / \mathrm{l}\right)$ and the yield of essential oil $\left(\mathrm{y}_{2}, \%\right.$ raw material) were chosen as dependent variables.

For statistical calculations the variables $X_{\mathrm{i}}$ were coded as $\mathrm{x}_{\mathrm{i}}$ according to Equation (1),

$$
x_{i}=\left(X_{i}-\bar{x}_{i}\right) /\left(\Delta x_{j}\right) \quad(i=1,2,3, \ldots, k)
$$

where $x_{i}$ is the dimensionless value of an independent variable, $X_{i}$ is the real value of an independent variable, $\bar{x}_{i}$ is the real value of the independent variable at the center point and $\Delta \mathrm{x}_{\mathrm{j}}$ is step change.

Table 2. Real values of the independent variables at their corresponding levels in the design.

\begin{tabular}{|l|c|c|c|c|c|c|}
\hline \multirow{2}{*}{\multicolumn{2}{|c|}{ Variables }} & \multicolumn{5}{c|}{ Coded levels } \\
\cline { 3 - 8 } & & $-\boldsymbol{\alpha}$ & $\mathbf{- 1}$ & $\mathbf{0}$ & $\mathbf{+ 1}$ & $\mathbf{+ \alpha}$ \\
\hline $\mathrm{pH}$ & $\left(\mathrm{X}_{1}\right)$ & 4.23 & 4.5 & 5.0 & 5.5 & 5.77 \\
\hline $\mathrm{T},{ }^{0} \mathrm{C}$ & $\left(\mathrm{X}_{2}\right)$ & 37.3 & 40 & 45 & 50 & 52.7 \\
\hline $\mathrm{t}, \mathrm{h}$ & $\left(\mathrm{X}_{3}\right)$ & 4.91 & 6 & 8 & 10 & 10.09 \\
\hline Laccase, $\mathrm{ml} / \mathrm{g}$ substrate & $\left(\mathrm{X}_{4}\right)$ & 0.245 & 0.3 & 0.4 & 0.5 & 0.555 \\
\hline Htec2, g/100g substrate & $\left(\mathrm{X}_{5}\right)$ & 1.1 & 1.25 & 1.5 & 1.75 & 1.89 \\
\hline
\end{tabular}

The chosen $2^{5-1}$ central composite design matrix (Table 3) consists of 16 factorial points (runs 1 - 16), 10 axial points (runs 17 - 26), and one center point (run 27). The $\alpha$-value of 1.546 was taken from tabulated data as described by Pham Hong Hai (2007) [8].

In order for the design matrix to be orthogonal, $\mathrm{x}_{\mathrm{j}}^{2}$ were linear transformed into $\mathrm{x}_{\mathrm{j}}^{\prime}$ by Equation (2).

$$
x_{j}^{\prime}=x_{j}^{2}-\overline{x_{j}^{2}}=x_{j}^{2}-\frac{\sum_{i=1}^{n} x_{j i}^{2}}{N}
$$

Thus, the relationship between the dependent and independent variables in this statistical model was described by a general second-order polynomial equation as follows:

$$
\hat{y}=b_{o}^{\prime}+\sum_{j=1}^{k} b_{j} x_{j}+\sum_{u, j=1}^{k} b_{u j} x_{u} x_{j}+\sum_{j=1}^{k} b_{j j} x_{j}^{\prime}
$$

In order to estimate the mean of square of pure error $S_{t s}^{2}$ associated with repetition, 03 replicates of experiments at center point were performed, yielding a set of response values of 77.71, 77.71, and 76.62 for y1 and another set of values of $0.972,0.973,0.968$ for y2. From these data sets, a value of 0.2984 was estimated for $S_{t s}^{2}$ of $\mathrm{y}_{1}$ and a value of $7 * 10^{-6}$ for $S_{t s}^{2}$ of $\mathrm{y}_{2}$. 
Hoang Thi Bich, et al.

Table 3. Design matrix and experimental results.

\begin{tabular}{|c|c|c|c|c|c|c|c|c|c|c|c|c|c|c|c|c|c|c|c|c|c|c|c|c|c|}
\hline Run & $\mathrm{x}_{0}$ & $\mathrm{x}_{1}$ & $\mathrm{x}_{2}$ & $x_{3}$ & $\mathrm{x}_{4}$ & $\mathrm{X}_{5}$ & $\mathrm{x}_{1} \mathrm{x}_{2}$ & $\mathrm{x}_{1} \mathrm{x}_{3}$ & $\mathrm{x}_{1} \mathrm{x}_{4}$ & $\mathrm{x}_{1} \mathrm{x}_{5}$ & $\mathrm{x}_{2} \mathrm{x}_{3}$ & $\mathrm{x}_{2} \mathrm{x}_{4}$ & $\mathrm{x}_{2} \mathrm{x}_{5}$ & $\mathrm{x}_{3} \mathrm{X}_{4}$ & $\mathrm{x}_{3} \mathrm{x}_{5}$ & $\mathrm{x}_{4} \mathrm{x}_{5}$ & $\mathrm{x}_{1}$ & $\mathrm{x}_{2}$ & $\mathrm{x}_{3}$ & $\mathrm{x}_{4}$ & $\mathrm{x}_{5}$ & $\mathrm{y}_{1}$ & $\hat{\mathrm{y}}_{1}$ & $\mathrm{y}_{2}$ & $\hat{y}_{2}$ \\
\hline 1 & + & - & - & - & - & + & + & + & + & - & + & + & - & + & - & - & 0.23 & 0.23 & 0.23 & 0.23 & 0.23 & 65.208 & 64.589 & 0.942 & 0.938 \\
\hline 2 & + & + & - & - & - & - & - & - & - & - & + & + & + & + & + & + & 0.23 & 0.23 & 0.23 & 0.23 & 0.23 & 64.19 & 65.542 & 0.953 & 0.944 \\
\hline 3 & + & - & + & - & - & - & - & + & + & + & - & - & - & + & + & + & 0.23 & 0.23 & 0.23 & 0.23 & 0.23 & 67.284 & 68.322 & 0.941 & 0.931 \\
\hline 4 & + & + & + & - & - & + & + & - & - & + & - & - & + & + & - & - & 0.23 & 0.23 & 0.23 & 0.23 & 0.23 & 69.598 & 69.275 & 0.943 & 0.937 \\
\hline 5 & + & - & - & + & - & - & + & - & + & + & - & + & + & - & - & + & 0.23 & 0.23 & 0.23 & 0.23 & 0.23 & 71.18 & 71.040 & 0.946 & 0.942 \\
\hline 6 & + & + & - & + & - & + & - & + & - & + & - & + & - & - & + & - & 0.23 & 0.23 & 0.23 & 0.23 & 0.23 & 71.494 & 71.993 & 0.945 & 0.948 \\
\hline 7 & + & - & + & + & - & + & - & - & + & - & + & - & + & - & + & - & 0.23 & 0.23 & 0.23 & 0.23 & 0.23 & 70.588 & 71.273 & 0.936 & 0.935 \\
\hline 8 & + & + & + & + & - & - & + & + & - & - & + & - & - & - & - & + & 0.23 & 0.23 & 0.23 & 0.23 & 0.23 & 72.57 & 72.255 & 0.947 & 0.941 \\
\hline 9 & + & - & - & - & + & - & + & + & - & + & + & - & + & - & + & - & 0.23 & 0.23 & 0.23 & 0.23 & 0.23 & 72.576 & 72.090 & 0.945 & 0.944 \\
\hline 10 & + & + & - & - & + & + & - & - & + & + & + & - & - & - & - & + & 0.23 & 0.23 & 0.23 & 0.23 & 0.23 & 72.89 & 73.042 & 0.947 & 0.950 \\
\hline 11 & + & - & + & - & + & + & - & + & - & - & - & + & + & - & - & + & 0.23 & 0.23 & 0.23 & 0.23 & 0.23 & 71.984 & 72.323 & 0.936 & 0.938 \\
\hline 12 & + & + & + & - & + & - & + & - & + & - & - & + & - & - & + & - & 0.23 & 0.23 & 0.23 & 0.23 & 0.23 & 73.966 & 73.275 & 0.946 & 0.943 \\
\hline 13 & + & - & - & + & + & + & + & - & - & - & - & - & - & + & + & + & 0.23 & 0.23 & 0.23 & 0.23 & 0.23 & 73.88 & 74.031 & 0.94 & 0.949 \\
\hline 14 & + & + & - & + & + & - & - & + & + & - & - & - & + & + & - & - & 0.23 & 0.23 & 0.23 & 0.23 & 0.23 & 75.844 & 74.984 & 51 & 0.954 \\
\hline 15 & + & - & + & + & + & - & - & - & - & + & + & + & - & + & - & - & 0.23 & 0.23 & 0.23 & 0.23 & 0.23 & 74.956 & 74.273 & 939 & 0.942 \\
\hline 16 & + & + & + & + & + & + & + & + & + & + & + & + & + & + & + & + & 0.23 & 0.23 & 0.23 & 0.23 & 0.23 & 75.27 & 75.226 & 0.946 & 0.947 \\
\hline 17 & + & -1.546 & 0 & 0 & 0 & 0 & 0 & 0 & 0 & 0 & 0 & 0 & 0 & 0 & 0 & 0 & 0.23 & 1.62 & $\begin{array}{c}- \\
0.77 \\
\end{array}$ & $\begin{array}{c}- \\
0.77 \\
\end{array}$ & $\begin{array}{c}- \\
0.77 \\
\end{array}$ & 74.594 & 72.618 & 0.962 & 0.947 \\
\hline 18 & + & +1.546 & 0 & 0 & 0 & 0 & 0 & 0 & 0 & 0 & 0 & 0 & 0 & 0 & 0 & 0 & 0.23 & 1.62 & $\begin{array}{c}- \\
0.77\end{array}$ & $\begin{array}{c}- \\
0.77 \\
\end{array}$ & $\begin{array}{c}- \\
0.77 \\
\end{array}$ & 75.714 & 74.091 & 0.966 & 0.959 \\
\hline 19 & + & 0 & -1.546 & 0 & 0 & 0 & 0 & 0 & 0 & 0 & 0 & 0 & 0 & 0 & 0 & 0 & 0.23 & 0.77 & 1.62 & $\begin{array}{c}- \\
0.77 \\
\end{array}$ & $\begin{array}{c}- \\
0.77 \\
\end{array}$ & 74.654 & 72.362 & 0.965 & 0.958 \\
\hline 20 & + & 0 & +1.546 & 0 & 0 & 0 & 0 & 0 & 0 & 0 & 0 & 0 & 0 & 0 & 0 & 0 & 0.23 & $\begin{array}{c}- \\
0.77 \\
\end{array}$ & 1.62 & $\begin{array}{c}- \\
0.77 \\
\end{array}$ & $\begin{array}{c}- \\
0.77\end{array}$ & 76.322 & 74.078 & 0.941 & 0.947 \\
\hline 21 & + & 0 & 0 & -1.546 & 0 & 0 & 0 & 0 & 0 & 0 & 0 & 0 & 0 & 0 & 0 & 0 & 0.23 & $\begin{array}{c}- \\
0.77\end{array}$ & $\begin{array}{c}- \\
0.77\end{array}$ & 1.62 & $\begin{array}{c}- \\
0.77\end{array}$ & 73.27 & 72.169 & 0.939 & 0.948 \\
\hline 22 & + & 0 & 0 & +1.546 & 0 & 0 & 0 & 0 & 0 & 0 & 0 & 0 & 0 & 0 & 0 & 0 & 0.23 & $\begin{array}{c}- \\
0.77\end{array}$ & $\begin{array}{c}- \\
0.77\end{array}$ & 1.62 & $\begin{array}{c}- \\
0.77\end{array}$ & 77.438 & 77.306 & 0.969 & 0.955 \\
\hline 23 & + & 0 & 0 & 0 & -1.546 & 0 & 0 & 0 & 0 & 0 & 0 & 0 & 0 & 0 & 0 & 0 & 0.23 & 0.77 & $\begin{array}{c}- \\
0.77\end{array}$ & 0.77 & $\begin{array}{c}- \\
0.77 \\
\end{array}$ & 74.872 & 71.294 & 0.93 & 0.957 \\
\hline 24 & + & 0 & 0 & 0 & +1.546 & 0 & 0 & 0 & 0 & 0 & 0 & 0 & 0 & 0 & 0 & 0 & 0.23 & $\begin{array}{c}- \\
0.77 \\
\end{array}$ & $\begin{array}{c}- \\
0.77\end{array}$ & $\begin{array}{c}- \\
0.77 \\
\end{array}$ & $\begin{array}{c}- \\
0.77 \\
\end{array}$ & 78.872 & 78.055 & 0.976 & 0.967 \\
\hline 25 & + & 0 & 0 & 0 & 0 & -1.546 & 0 & 0 & 0 & 0 & 0 & 0 & 0 & 0 & 0 & 0 & 0.23 & $\begin{array}{c}- \\
0.77 \\
\end{array}$ & $\begin{array}{c}- \\
0.77 \\
\end{array}$ & $\begin{array}{c}- \\
0.77 \\
\end{array}$ & 1.62 & 77.136 & 77.749 & 0.962 & 0.971 \\
\hline 26 & + & 0 & 0 & 0 & 0 & +1.546 & 0 & 0 & 0 & 0 & 0 & 0 & 0 & 0 & 0 & 0 & 0.23 & 0.77 & 0.77 & 0.77 & 1.62 & 76.482 & 77.749 & 0.965 & 0.971 \\
\hline 27 & + & 0 & 0 & 0 & 0 & 0 & 0 & 0 & 0 & 0 & 0 & 0 & 0 & 0 & 0 & 0 & 0.23 & 0.77 & $\begin{array}{c}- \\
0.77 \\
\end{array}$ & 0.77 & $\begin{array}{c}- \\
0.77 \\
\end{array}$ & 78.118 & 77.749 & 0.976 & 0.971 \\
\hline
\end{tabular}





\subsection{Mathematic - statistical treatment and validation of the model}

Because the design matrix is orthogonal, the coefficients bj and their variances $S_{b_{j}}^{2}$ can be directly estimated according to Equation (4) and (5).

$$
\begin{aligned}
& \mathrm{b}_{\mathrm{j}}=\frac{\sum_{i=1}^{N} x_{j i} y_{i}}{\sum_{i=1}^{N} x_{j i}^{2}} ; \mathrm{j}=\overline{1, \mathrm{k}} \\
& S_{b_{j}}^{2}=\frac{S_{t s}^{2}}{\sum_{i=1}^{N} x_{j i}^{2}}
\end{aligned}
$$

Replacing the quadratic terms related to $x_{j}^{\prime}$ in Equation (3) using Equation (2) we obtained the normal form of the polynomial Equation (3) as follows:

Thus,

$$
\begin{aligned}
& \hat{\mathrm{y}}=b_{o}^{\prime}+\sum_{j=1}^{k} b_{j} x_{j}+\sum_{u, j=1}^{k} b_{u j} x_{u} x_{j}+\sum_{j=1}^{k} b_{j j} x_{j}^{2} \\
& \mathrm{~b}_{\mathrm{o}}=b_{o}^{\prime}-b_{11} \overline{x_{1}^{2}}-\ldots \ldots .-b_{k k} \overline{x_{k}^{2}}
\end{aligned}
$$

The software package Design Expert 7.0 was used for the calculations of the established data. The experimental and predicted values were presented in Table 3.

The second-order polynomial Equation (8) was obtained for the dependent variable $\hat{y}_{1}$ (reducing sugar outcome) as follows:

$$
\begin{array}{r}
\hat{\mathrm{y}}_{1}=79.728+0.476 \mathrm{x}_{1}+0.555 \mathrm{x}_{2}+1.662 \mathrm{x}_{3}+2.187 \mathrm{x}_{4}+0.439 \mathrm{x}_{1} \mathrm{x}_{5}-0.436 \mathrm{x}_{2} \mathrm{x}_{3}-0.436 \mathrm{x}_{2} \mathrm{x}_{4} \\
-0.689 \mathrm{x}_{3} \mathrm{x}_{4}-1.979 \mathrm{x}_{1}^{2}-1.839 \mathrm{x}_{2}^{2}-1.825 \mathrm{x}_{3}^{2}-1.26 \mathrm{x}_{4}^{2}-1.286 \mathrm{x}_{5}^{2}
\end{array}
$$

with: $S_{t s}^{2}=0.2984$ as determined above, statistical calculations afforded:

- The estimated variances of the regression coefficients,

$$
\mathrm{S}_{b_{j}}=0.09001 ; \mathrm{S}_{b_{u j}}=0.09657 ; \mathrm{S}_{b_{j j}}=0.16158 \text {. }
$$

- The $\mathrm{t}$-values for the regression coefficients, $\mathrm{t}_{1}=5.288 ; \mathrm{t}_{2}=6.161 ; \mathrm{t}_{3}=18.447 ; \mathrm{t}_{4}=24.275$; $\mathrm{t}_{15}=4.542 ; \mathrm{t}_{23}=4.519 ; \mathrm{t}_{24}=4.519 ; \mathrm{t}_{34}=7.131 ; \mathrm{t}_{11}=12.245 ; \mathrm{t}_{22}=11.381 ; \mathrm{t}_{33}=11.728 ; \mathrm{t}_{44}=$ 7.799; $\mathrm{t}_{55}=7.962$. All $\mathrm{t}$-values were higher than the tabulated value $\mathrm{t}_{\mathrm{p}}(\mathrm{f})=\mathrm{t}_{0,05}(2)=4.3$, indicating that the regression coefficients in Equation (8) were significant.

- An F-value of 10.304, which is lower than the tabulated value $F_{p}\left(f_{1}, f_{2}\right)=F_{0.05}(13,2)=19.4$, indicating that the mathematical model was well fitted to the experimental data.

The second-order polynomial Equation (9) was obtained for the dependent variable $\hat{y}_{2}$ (oil yield) as follows:

$$
\begin{array}{r}
\hat{y}_{2}=0.97498+0.00285 \mathrm{x}_{1}-0.00347 \mathrm{x}_{2}+0.00209 \mathrm{x}_{3}+0.00328 \mathrm{x}_{4}-0.00373 \mathrm{x}_{1}^{2}-0.00833 \\
\mathrm{x}_{2}{ }^{2}-0.00791 \mathrm{x}_{3}^{2}-0.00833 \mathrm{x}_{4}{ }^{2}-0.00394 \mathrm{x}_{5}^{2}
\end{array}
$$

with $\mathrm{S}_{\mathrm{ts}}^{2}=7.10^{-6}$; as determined above, statistical calculations afforded:

- The estimated variances of the regression coefficients,

$$
\mathrm{s}_{\mathrm{bj}}=4.3626 .10^{-4} ; \mathrm{s}_{\mathrm{buj}}=4.6771 .10^{-4}, \mathrm{~s}_{\mathrm{bjj}}=7.8253 .10^{-4} \text {. }
$$

- The $t$-values for the regression coefficients, $t_{1}=6.528 ; t_{2}=7.954 ; t_{3}=4.785 ; t_{4}=$ $7.514 ; \mathrm{t}_{11}=4.769 ; \mathrm{t}_{22}=10.647 ; \mathrm{t}_{33}=10.112 ; \mathrm{t}_{44}=10.647 ; \mathrm{t}_{55}=5.031$. All $\mathrm{t}$-values were higher than the tabulated value $\mathrm{t}_{\mathrm{p}}(\mathrm{f})=\mathrm{t}_{0,05}(2)=4.3$, indicating that the regression coefficients in Equation (9) were significant. 
- $\quad$ An F-value of 17.467, which is lower than the tabulated value $F_{p}\left(f_{1}, f_{2}\right)=F_{0.05}(17,2)=19.45$, indicating that the mathematical model was well fitted to the experimental data.

Equation (8) and (9) showed that all 05 parameters exert an effect on the output of the process. Furthermore, 3D presentation of the response surfaces described by Equation (8) showed interactions of 4 pairs of parameters. A visual example of interaction between the parameters $\mathrm{x}_{2}$ (temperature) and $\mathrm{x}_{3}$ (time) is demonstrated in Figure 1.
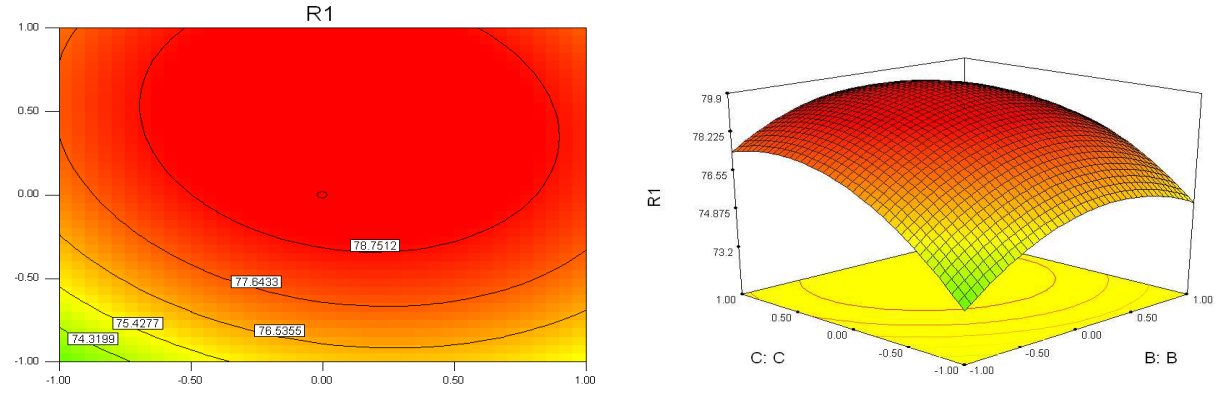

Figure 1. Response surface showing interactive effect of temperature $\left(\mathrm{x}_{2}\right)$ and time $\left(\mathrm{x}_{3}\right)$.

\subsection{Determination of the optimal conditions}

As the yield of essential oil is the goal, Equation (9) was used for the optimization of the process. Statistical calculations were performed using an algorithm of flexible tolerance method with the following constraints:

$$
\begin{gathered}
-1.546 \leq \mathrm{x}_{\mathrm{j}} \leq 1.546(\mathrm{j}=1, \ldots, 5) \\
\hat{\mathrm{y}}_{1} \geq 70 \mu \mathrm{g} / \mathrm{ml}
\end{gathered}
$$

The obtained results afforded the optimum values for each independent variable $\mathrm{x}_{\mathrm{j}}$ as follows:

$$
x_{1}^{o p t}=0.384 ; x_{2}^{o p t}=-0.209 ; x_{3}^{o p t}=1.546 ; x_{4}^{o p t}=0.192 ; x_{5}^{o p t}=0.023
$$

The corresponding real values were:

$$
\mathrm{pH}=5.2 ; \mathrm{T}=44^{\circ} \mathrm{C} ; \tau=5 \mathrm{~h} 30^{\prime} ; \text { Laccase }=0.42 \mathrm{ml} / \mathrm{g} \text { and } \mathrm{Htec} 2=1.15 \% .
$$

An experiment performed using these parameters gave $78.14 \mu \mathrm{g} / \mathrm{ml}$ reducing sugar and $0.982 \%$ yield of essential oil, which was close to the predicted value $(0.978 \%)$.

\section{CONCLUSSION}

The application of the response surface methodology, in this particular case, the application of a fractional and orthogonal central composite design to construct a statistical model of the process has led to second-order polynomials that fitted well with the experimental data and described in detail the effects of individual parameter as well as their interactive effects. Furthermore, the model enabled a reliable estimation of optimal process parameters. The application of enzyme complex to assist the extraction of essential oil from cassia leaves and branches in combination with the application of the response surface methodology substantially improved the oil yield (41.94\% increase as compared with control experiment). 
Acknowledgements. This work has been partly completed with financial support from the research project of the Vietnam Academy of Science and Technology "Study on chemical composition, survey and assessment of the quality of agarwood oils produced in Vietnam", project code VAST 04.

\section{REFERENCES}

1. La Dinh Moi, Luu Dam Cu, Tran Minh Hoi, Nguyen Thi Thuy, Nguyen Thi Phuong Thao, Tran Huy Thai, Ninh Khac Ban - Essential Oil Plants in Vietnam, Agriculture Publishing House, Vol. I, Hanoi, 2000, pp. 198-206 (in Vietnamese).

2. Hoang Thi Bich, Le T. T., Tran Q. T., Nguyen H. T., Le X. D., Nguyen V. T. A., Dinh T. T. T., Tran T. T., Do T. S., Le M. H. and Nguyen Q. C. - Investigation of enzyme treatments to assist extraction of essential oil from the leaves and branches of Cinnamomum cassia collected in Yenbai province. Vietnam Journal of Science and Technology 54 (2C) (2016) 486-492.

3. Bezerra M. A., Santelli R. E., Oliveira E. P., Villar L. S. and Escaleira L. A. - Response surface methodology (RSM) as a tool for optimization in analytical chemistry, Talanta $\mathbf{7 6}$ (5) (2008) 965-977.

4. Vu Dinh Giap, Do Huu Chi, Pham Hong Hai, Tang Thi Chinh and Do Huu Nghi - Using Experimental Planning to Optimize the Hydrolysis of Sugar Cane Bagasse into Fermentable Sugars for Bioethanol Production by Fungal Enzyme Mixture, Vietnam Journal of Science and Technology 55 (4) (2017) 419-428.

5. Miller G. L. - Use of dinitrosalicylic acid reagent for determination of reducing sugar, Anal. Chem. 3 (1959) 426-428.

6. Ministry of Public Health-Vietnam Pharmacopoeia IV, Medical Publishing House, Hanoi, (2009), pp. 962 (in Vietnamese).

7. Box G. E. P. and Wilson K. B. - 1951 On the experimental attainment of optimum conditions, Journal of the Royal Statistical Society (Series B) 13 (1951) 1-45.

8. Pham Hong Hai, Ngo Kim Chi - The data analysis and planning of experiments in chemical research. Natural Science and Technology Publishing House, Hanoi, 2007, pp. 89-104 (in Vietnamese). 